\title{
Differential Object Marking in Turkic and Persian as a Contact Phenomenon
}

GREG KEY

The University of Arizona

\section{Object Marking in Turkish, Persian, and the Languages of Iranian Azerbaijan. ${ }^{1}$}

Despite the absence of genetic affiliation, Turkish (SW Turkic) and Persian (SW Iranian) have nearly identical differential object marking patterns. Herein it is proposed that this is due in part to contact between Persian and Azerbaijanian, which is closely related to Turkish, and that Iranian Azerbaijan is an isogloss for this feature. The tableau of evidence is a large puzzle only a few pieces of which have been filled in. In this work, I present several of those pieces. Part 1 contains synchronic evidence of object marking patterns in various languages both inside and outside the proposed isogloss, while Part 2 contains the result of a study comparing object marking in Old Anatolian Turkish and Classical Persian manuscripts.

\subsection{The Turko-Persian Pattern of Differential Object Marking (DOM)}

Differential Object Marking (DOM) is the morphological marking of some direct objects and not of others, based on hierarchies such as animacy and referentiality (Bossong 1985, 1981; Aissen 2003). The Persian marker is $-r a ̂$ in the formal language, colloquially realized as $-r o$ following a vowel and $-O$ following a consonant. The Turkish object marker is $-I$ following a consonant and $-y I$ following a vowel, where $I$ represents a high vowel realized as front or back, rounded or unrounded, according to the rules of Turkish vowel harmony.

The following marking pattern holds in both languages, regardless of the animacy of the object. Definite objects are obligatorily marked. Indefinite objects

\footnotetext{
${ }^{1}$ Thanks to Davoud Zamani for Iranian Azerbaijanian, and to Simin Karimi for Persian grammaticality judgments.
} 
are usually unmarked, but may be marked under certain conditions. ${ }^{2}$ Bare nominal objects (having no determiner or indefiniteness morphology) have a definite singular interpretation when marked, and a kind-level interpretation when unmarked. A kind-level noun (Karimi 2005) is unspecified for number, and nonreferential (also called categorial (Göksel \& Kerslake 2005)).

Feature 1: Definite objects are obligatorily marked. ${ }^{3}$

Persian

(1) Kimea ketâb-o xund.

Kimea book-OM read

'Kimea read the book.'

Turkish

(2) Ayşe kitab-ı okudu.

Ayşe book-OM read

'Ayşe read the book.'

Feature 2: Indefinite objects are usually unmarked, but may be marked.

Persian

(3) a. Kimea

Kimea one dastan-(i)_-goft

one story-IND- $\varnothing$ said

'Kimea told a story.'

b. Kimea ye dâstân-i-ro goft ke az to

Kimea one story-REL-OM told that from you

šenide bud.

heard was

'Kimea told a story that (she) had heard from you.' (Karimi 2005: 27)

Turkish

(4) a. Bazen masa-ya bir örtü-_ yay-ar-dl-k.

sometimes table-DAT one cloth- $\varnothing$ spread-AOR-PST-2PL

'Sometimes we would spread a cloth on the table.'

\footnotetext{
${ }^{2}$ Marking of indefinites is claimed to be based on the specificity of the object (Enç 1991 for Turkish, Karimi 2005 for Persian). However, not all authors are in agreement on this, nor indeed on the proper characterization of 'specificity' (see Ghomeshi 1997, von Heusinger \& Kornfilt 2005). Given the difficulty of characterizing specificity independently in either language, I will not address it in the present cross-linguistic study.

${ }^{3}$ Abbreviations: ABL ablative, AOR aorist, DAT dative, DUR durative, ERG ergative, GEN genitive, IMP imperative, IND indefinite, NOM nominative, OM object marker, POSS possessive, DEF definite, NEG negative, OBL oblique, OPT optative, PERF perfect, PL plural, PRET preterit, PST past, SG singular.
} 
b. Bazen masa-ya Ayşe-nin bize Meksika-dan sometimes table-DAT Ayşe-GEN we-DAT Mexico-ABL

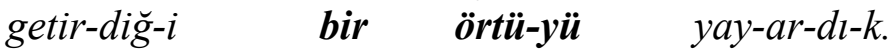
bring-PRT-3SG one cloth-OM spread-AOR-PST-2PL 'Sometimes we would spread on the table a cloth that Ayşe had brought us from Mexico.' (Göksel and Kerslake 2005: 375-376)

Feature 3: Bare nominal objects have a definite singular interpretation when marked, and a kind-level interpretation (unspecified for number, and nonreferential) when unmarked. For convenience's sake, the kind-level object ketâb/kitap is translated as 'a book/books'; however, it should be noted that 'book' as a kind-level object does not imply that any book was read in its entirety, and hence predicates taking kind-level objects are atelic.

Persian

(5) a. Kimea

ketâb-o xund.

Kimea book-OM read

'Kimea read the book.'

b. Kimea ketâb-_ xund.

Kimea book-ø read

'Kimea read a book/books.'

Turkish

(6) a. Ayşe kitab-ı okudu.

Ayşe book-OM read

'Ayşe read the book.'

b. Ayşe kitap-_ okudu.

Ayşe book- $\varnothing$ read

'Ayşe read a book/books.'

\subsection{DOM in Other Turkic and Persian Languages}

Is this shared pattern due to contact? Although Turkey and Iran are contiguous, Turkish and Persian do not share a contact area. Literary Turkish of the Ottoman Empire was under influence from literary Persian, but the reverse was not true. However, Persian is in contact with Azerbaijanian (SW Turkic), a close relative of Turkish. The contact zone is Iranian Azerbaijan (in northwestern Iran). The Azerbaijanian language spoken in Iran has the same DOM pattern. 


\section{Greg Key}

Feature 1: Definite objects are obligatorily marked.

\section{(7) Aisha kitab-ı okhudu. \\ Aisha book-OM read \\ 'Aisha read the book.'}

Feature 2: Indefinite objects are usually unmarked, but may be marked.
(8) Iran barasında bir kitab-_kitab-ı akhtar-ır-am.
Iran about a book-ø/book-OM search-PRES-1SG

'I'm looking for a book about Iran.'

Feature 3. Bare nominal objects have a definite singular interpretation when marked, and a kind-level interpretation when unmarked.

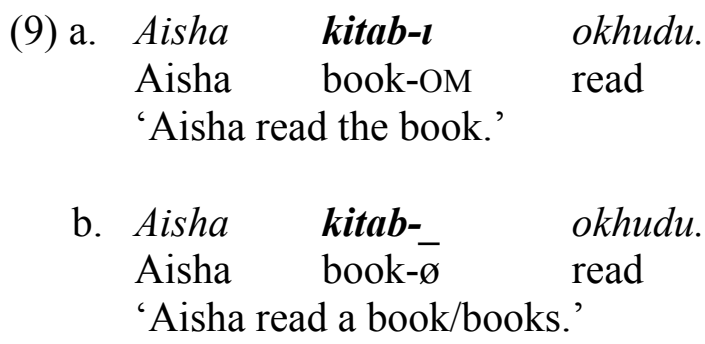

Since the contact area for Persian and Azerbaijanian is Iranian Azerbaijan, I propose that this area is an isogloss for the DOM pattern identified herein. As a first step in investigating this proposal, it is necessary to determine the distribution of this pattern both inside and outside of the proposed isogloss. The present study represents the rudimentary beginnings of such a project.

The languages spoken in Iranian Azerbaijan include Azerbaijanian (SW Turkic), Eastern Armenian (precise affiliation within the Indo-European family unclear), and the Iranian languages Persian (SW), Tatic (Tati, Taleshi), Gilaki, and Mazanderani (NW).

Eastern Armenian shows evidence of the pattern. In the dialect spoken in Iran, the morpheme $\partial(/ \mathrm{n} /$ after vowels $)$ differentially marks direct objects (Megerdoomian 2008). In traditional grammars, this is identified as the definite article. According to Megerdoomian, it is the marker for inanimate objects. The form -an is used for animates but apparently has the same differential properties with regard to definiteness. (The glosses have been slightly modified; in particular, Megerdoomian's gloss ACC (accusative) has been changed to OM.) 'YES' indicates a feature's presence, while 'NO' indicates its absence. 
Feature 1: YES

$\begin{array}{lll}\text { Ara- } n & \text { girk'-o } & \text { ayr-ets } \\ \text { Ara-NOM } & \text { book-OM } & \text { burned }\end{array}$

'Ara burned the book.' (Megerdoomian 2008)

Feature 2: YES

$$
\begin{array}{llll}
\text { Ara-n } & m i & \text { girk'-_/girk'-o } & \text { ayr-ets } \\
\text { Ara-NOM } & \text { one } & \text { book-ø/book-OM } & \text { burned }
\end{array}
$$

'Ara burned a book/one book.' (Megerdoomian 2008)

Feature 3: YES

(12) a. Sirun-a

xəndzor-o ker-av

Sirun-NOM apple-OM

'Sirun ate the apple.'

b. Sirun-a xandzor-_ ker-av

Sirun-NOM apple-OM eat-AOR/3SG

'Sirun ate an apple/apples.' (Megerdoomian 2008)

At present I have scant data on DOM in NW Iranian languages, limited to examples in Bossong (1985) and Windfuhr (2009), which for the most part provide information on Feature 1 only. I will therefore limit the discussion of these languages to this feature.

Since inanimates are lower on the animacy hierarchy than animates, the marking of definite inanimate objects entails the marking of definite animates (Aissen 2003). Therefore, examples of marked inanimate objects are taken as evidence that marking is possible for all definite objects, regardless of animacy. Furthermore, the absence of any examples with unmarked definite objects leaves open the possibility that the marking of definite objects is obligatory. Such languages are tentatively considered to have Feature 1, the possibility that they exhibit full pattern remaining open (including Features 2 and 3).

Examples with unmarked definite objects are taken to mean that the language in question does not exhibit Feature 1, and hence does not exhibit the TurkoPersian DOM pattern. For Tati, Taleshi, Gilaki and Mazanderani, Bossong gives examples of unmarked indefinite objects, both animate and inanimate, showing that these languages have DOM. He provides no examples with unmarked definite direct objects, leaving open the possibility that these languages have Feature 1. (Again, the glosses have been modified slightly for consistency.)

Feature 1: Definite objects are obligatorily marked.

Tati

$$
\begin{aligned}
& \ddot{a} \quad \text { täxtä musmar-ä män bä-kälbäti-raz väkänd-ÿm } \\
& \text { from board nail-OM I to.pliers.with pull.out-1SG }
\end{aligned}
$$

'I pulled the nail out of the board with a pair of pliers.' (Bossong 1985:

56) 


\section{Greg Key}

There are no definite objects among Bossong's examples of unmarked objects.

Taleshi

tâbut-e bə-nia zamin.

coffin-OM CONJ-sets ground

'... sets the coffin on the ground.'

\section{Gilaki}

$\begin{array}{lll}\text { samavər-a åtəš } & \text { bu-kun } \\ \text { Samovar-ACC fire } & \text { CONJ-do } \\ \text { 'Light the samovar!' } & \end{array}$

\section{Mazanderani \\ joekzan in harf-râ bä-šni-a onewomanthis word-OM PRET-hear-3SG}

'A woman heard these words.'

Kurdish varieties, on the other hand, which are not spoken in Iranian Azerbaijan, lack the pattern. Sorani Kurdish entirely lacks morphological marking of objects altogether (Thackston 2006b). Kurmanji Kurkish, on the other hand, exhibits split ergativity. In the present tense, feminine nouns are marked OBL regardless of definiteness or specificity (i.e., marking is non-differential). Masculine nouns are not marked unless preceded by a demonstrative (Thackston 2006a).

\begin{tabular}{|c|c|c|c|}
\hline $\begin{array}{l}\text { Ez na-ç-im } \\
\text { 1 SG NEG-go-1SG }\end{array}$ & $\begin{array}{l}\text { doktor. Ez } \\
\text { doctor } 1 \mathrm{SG}\end{array}$ & $\begin{array}{l}\text { derman-- } \\
\text { medicine- } \varnothing\end{array}$ & $\begin{array}{l}v e-n a-x w \text {-im. } \\
\text { PRV-NEG-drink-1SG }\end{array}$ \\
\hline $\begin{array}{l}\boldsymbol{i}-\boldsymbol{y} \hat{\boldsymbol{e}} \\
\text { nes-OB }\end{array}$ & $\begin{array}{ll}j i & \text { nax } \\
\text { also } & \text { NEG }\end{array}$ & $\begin{array}{l}i m . \\
\text { ant-1SG }\end{array}$ & \\
\hline
\end{tabular}

'I'm not going to the doctor. I'm not taking medicine. I don't want stitches, either.' (Thackston 2006a: 35)

$\begin{array}{llll}E z & \boldsymbol{w} \hat{\boldsymbol{\imath}} & \boldsymbol{d e r m a n}-\hat{\boldsymbol{\imath}} & \text { ve-na- } x w-i m . \\ 1 \mathrm{SG} & \text { that } & \text { medicine-OB } & \text { PRV-NEG-drink-1SG }\end{array}$

Vafsi (NW Iranian), spoken outside of Iranian Azerbaijan, has DOM but not the Turko-Persian variety. It is also split ergative, and has DOM in the present tense only, where animate, specific objects are marked oblique (Stilo 2004). 
Feature $1-\mathrm{NO}$

Definite animate: marked

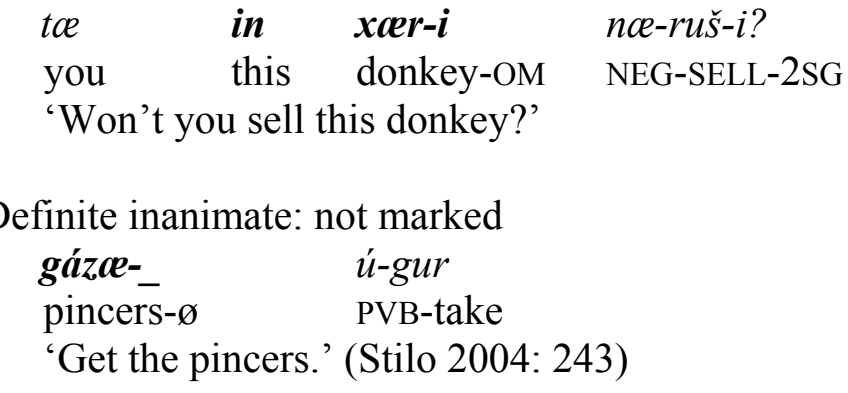

The NW Iranian languages that appear to exhibit Feature 1 have a contiguous distribution in northwest Iran (see Figure 2). NW Iranian languages that clearly lack Feature 1 are found along this region's southern and western periphery. Note that the languages lacking this feature are surrounded by languages that have it, not only in NW Iran, but also Persian to the south and Turkish to the west. This distribution is consistent with a model wherein NW Iranian initially lacked the feature, but NW Iranian languages in Iranian Azerbaijan and the Caspian region later acquired it. It is also noteworthy that the these languages pattern together in seven of the eight isoglosses discussed in Stilo (2005).

It is also necessary to determine the DOM patterns in Turkic and Iranian languages farther afield from Iranian Azerbaijan. Here especially, an immense amount of work remains to be done.

Uzbek (SE Turkic) appears to have Features 1 and 2 (data from Raun 1969). I do not currently have information on Feature 3.

Feature 1

$$
\begin{aligned}
& \text { kitop-ni oqiydi } \\
& \text { book-OM reads } \\
& \text { 'He reads the book.' }
\end{aligned}
$$

Feature 2

(22) men-ga bir stakan suw ber-in!

1SG-DAT a glass water give-IMP

'Give me a glass of water!' (Raun 1969: 20)

Raun points out that '-ni may also be used to denote a less definite, or even indefinite object' (p. 20), although he gives no such examples. This indicates that Uzbek has Feature 2 as well.

As for geographically removed Iranian languages, Tajik, a variety of Persian spoken in Tajikistan and Uzbekistan also has Features 1 and 2 (Windfuhr \& Perry 2009: 485). It is difficult to know exactly what to make of this. On the one hand, Tajik is a variety of Persian, and hence may inherit this feature from Persian 
generally. On the other hand, there is a plethora of contact situations in Central Asia, and there may be more than one isogloss for this trait.

Feature 1

(23) kitob-ro xarid-am book-OM bought-1SG

'I bought the book.'

Feature 2

\begin{tabular}{|c|c|c|}
\hline $\begin{array}{c}(y a k) \\
\text { one }\end{array}$ & $\begin{array}{l}\text { zan[-e]-ro } \\
\text { woman-IND-OM }\end{array}$ & $\begin{array}{l}\text { did-am } \\
\text { saw-1SG }\end{array}$ \\
\hline
\end{tabular}

On the other hand, Hindi/Urdu (Indo-Iranian, Indic branch; India, Pakistan) lacks Feature 1.
(25) a. Ravii-ne kaccaa kelaa-_ kaataa. Ravi-ERG unripe banana- $\varnothing$ cut.PRF
'Ravi cut the unripe banana.'
b. Ravii-ne kacce kele-ko kaataa.
Ravii-ERG unripe banana-OM cut.PRF
'Ravi cut the unripe banana.' (Mohanan 1994a: 87-88)

\section{Textual Evidence from Early New Persian and Old Anatolian Turkish}

DOM patterns in the historical predecessors of Turkish/Azerbaijanian and Persian are another important piece of the puzzle. In Old Turkic $\left(8^{\text {th }}-13^{\text {th }}\right.$ centuries AD), non-specific objects are never marked, but marking for definites is optional (Erdal 2004). In Old Persian $\left(6^{\text {th }}-4^{\text {th }}\right.$ centuries BC), the accusative marker was not differential (i.e., it was used on all direct objects). Middle Persian (300 BC-AD 900) marked some objects, but it is not clear if its use was differential (Brunner 1977).

In the following, a study of two medieval texts, one Early New Persian (ENP) and one Old Anatolian Turkish (OAT), is presented. These were analyzed to determine the distribution of object markers on direct objects based on objects' definiteness and animacy. ENP data were collected from a facsimile of an early 14th-century copy of the Nasihat-nâme of Onsorolma'âli Kaykâ'us (Leiden Codex, dated AH 719/AD 1319), while OAT data were collected from a late-14thcentury copy of a translation of the Nasihat-nâme (Birnbaum MS T 12, date missing). The original Persian was composed in the late $11^{\text {th }}$ century. The Turkish manuscript is considerably shorter due to lacunae in the extant manuscript, and consequently fewer data were collected from it. Only the narrative portions of the texts were included. 
In some sense, the texts are less than ideal for comparison, since they are from different centuries. However, the fact that the OAT text is a translation of the ENP text has some advantages. First, it allows us to compare identical examples in the two languages. Next, it makes clear that, as seen below, the Turko-Persian pattern found in OAT is not a translation effect.

Table 1. The distribution of marked and unmarked objects in the PQN

\begin{tabular}{|c|c|c|c|c|c|c|c|c|}
\hline & \multicolumn{2}{|c|}{ +human } & \multicolumn{2}{|c|}{$\begin{array}{l}\text {-human/ } \\
\text { +animate }\end{array}$} & \multicolumn{2}{|c|}{-animate } & \multicolumn{2}{|c|}{ Total } \\
\hline & $=r \hat{a}$ & $\varnothing$ & $=r \hat{a}$ & $\varnothing$ & $=r \hat{a}$ & $\varnothing$ & $=r \hat{a}$ & \\
\hline Pronoun & 54 & 0 & 2 & 0 & 0 & 23 & 56 & 23 \\
\hline Proper Name & 18 & 0 & 0 & 0 & 1 & 2 & 19 & 2 \\
\hline Definite Common NP & 23 & 2 & 3 & 2 & 9 & 177 & 35 & 181 \\
\hline Indefinite Common NP & 9 & 23 & 1 & 4 & 4 & 157 & 14 & 184 \\
\hline Total & 104 & 25 & 6 & 6 & 14 & 359 & 124 & 390 \\
\hline Combined Total & \multicolumn{2}{|l|}{129} & \multicolumn{2}{|l|}{12} & \multicolumn{2}{|l|}{373} & \multicolumn{2}{|l|}{514} \\
\hline Doubtful definiteness & 3 & & & & 2 & 17 & & \\
\hline
\end{tabular}

Table 2. The distribution of marked and unmarked objects in the TQN

\begin{tabular}{|c|c|c|c|c|c|c|c|c|}
\hline & \multicolumn{2}{|c|}{ thuman } & \multicolumn{2}{|c|}{$\begin{array}{l}\text {-human/ } \\
\text { +animate }\end{array}$} & \multicolumn{2}{|c|}{-animate } & \multicolumn{2}{|c|}{ Total } \\
\hline & $=(y) I$ & $\varnothing$ & $=(y) I$ & $\varnothing$ & $=(y) I$ & $\varnothing$ & $=(y) I$ & $\varnothing$ \\
\hline Pronoun & 45 & 0 & 0 & 0 & 23 & 0 & 68 & 0 \\
\hline Proper Name & 9 & 0 & 0 & 0 & 2 & 0 & 11 & 0 \\
\hline Definite Common NP & 14 & 0 & 5 & 0 & 105 & 7 & 124 & 7 \\
\hline Indefinite Common NP & 5 & 16 & 1 & 2 & 22 & 116 & 28 & 134 \\
\hline Total & 73 & 16 & 6 & 2 & 152 & 123 & 231 & 141 \\
\hline Combined Total & \multicolumn{2}{|l|}{89} & \multicolumn{2}{|l|}{8} & \multicolumn{2}{|l|}{275} & \multicolumn{2}{|l|}{372} \\
\hline Doubtful definiteness & & & 1 & & 11 & 12 & & \\
\hline
\end{tabular}

Human definite nouns were as a rule marked in both texts. There are two exceptions in the PQN (see Key 2008 for discussion) and none in the TQN. In both, human indefinites were sometimes marked but more frequently unmarked. The main divergence between the texts is in the marking of inanimate definite common nouns, which, as mentioned in Section 1, is an important diagnostic for Feature 1.

In the PQN, only 9 out of 186 inanimate definite objects are marked, while in the TQN 105 out of 112 inanimate definite objects are marked. 
(26)

$\begin{array}{llllll}\text { sâqi } & \text { nabid-_ } & \text { bed-in qâzi } & \text { dâd čun qâzi } \\ \text { cupbearer } & \text { wine- } \varnothing & \text { to-this judge } & \text { gave } & \text { when judge } \\ \text { nabid-_ } & \text { mi-setad } & \text { dar gholâm } & \text { negâh } & \text { kard... } \\ \text { wine- } \varnothing & \text { DuR-take } & \text { at slaveboy } & \text { look } & \text { did }\end{array}$

'The cupbearer gave wine to this judge, when the judge took the wine he looked at the slaveboy.' (PQN 95b)

\begin{tabular}{llll} 
sâqi & šarap-_ getür-di & šarab-ï & al-ur-iken \\
cupbearer & wine- $\varnothing$ bring-PST & wine-OM & take-AOR-while \\
$b u$ & sâqi-nüy & yüz-in-e & baq-di \\
this & cupbearer-GEN & face-POSS-DAT & look-PST \\
'The cupbearer brought wine. As he took the wine, he looked at this \\
\multicolumn{2}{l}{ cupbearer's face.' (TQN 114a) }
\end{tabular}

This shows that the EPN variety exemplified in the PQN clearly lacked Feature 1, and hence the Turko-Persian pattern as a whole. In the TQN, on the other hand, the fact that 7 out of 112 inanimate definites (6.25\%) were unmarked shows that the pattern was not absolute, but that marking was overwhelmingly the rule.

With respect to Feature 2, the PQN treated animate indefinites much as modern Persian does, but not inanimate indefinites, of which only 4 out of 157 were marked $(2.5 \%)$. The TQN, on the other hand, marked such objects at a much higher rate, 22 out of $116(19 \%)$.

Animate indefinites:

PQN

(28) mo'tasim vaqti mojrem-i-râ piš-e xwiš kardan hami mutasim when criminal-IND-OM front-EZ self make DUR farmud commanded 'When Mutasim commanded that [they] bring a criminal before him...' (PQN 31b)

\section{TQN}

$\begin{array}{lllll}\text { mu'tasim...bir } & \text { sučlu-yï } & \text { buyur-dï } & \text { kim } & \text { getür-e-ler } \\ \text { mutasim... a } & \text { criminal-OM } & \text { command-PST that } & \text { bring-OPT-PL } \\ \text { 'Mutasim...commanded that they bring a criminal forward' (TQN 48a) }\end{array}$


Inanimate indefinites:

PQN

(30) šenid-am ke vaqti sâheb esmâilben 'ubbâdnân-_ hami heard-1SG that when sir Ismail bin 'ubbad bread-ø CNT xord bâ nadimân-e xwiš mard-i loqma-i-_ ate with companions-EZ own man-IND morsel-IND- $\varnothing$ az kâse bar-dâšt

from bowl picked.up

'I heard that when sir Ismail Ubbad was eating bread with his companions, a man picked up a morsel from the bowl' (PQN 27a)

TQN

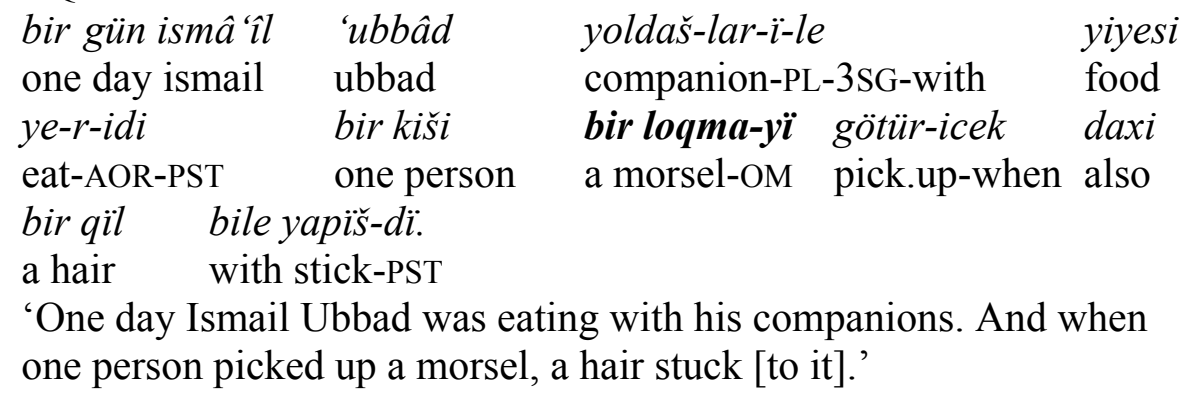

As for Feature 3, there is a dearth of evidence of kind-level objects in both manuscripts. There is a singled shared example.

PQN

$\begin{array}{lll}\boldsymbol{x a t t}-\boldsymbol{e} & \text { mozavvar-} & \text { kard- } i \\ \text { letter-EZ } & \text { forged-ø } & \text { did-HAB }\end{array}$

'He wrote forged letters.' (PQ 100a)

TQN

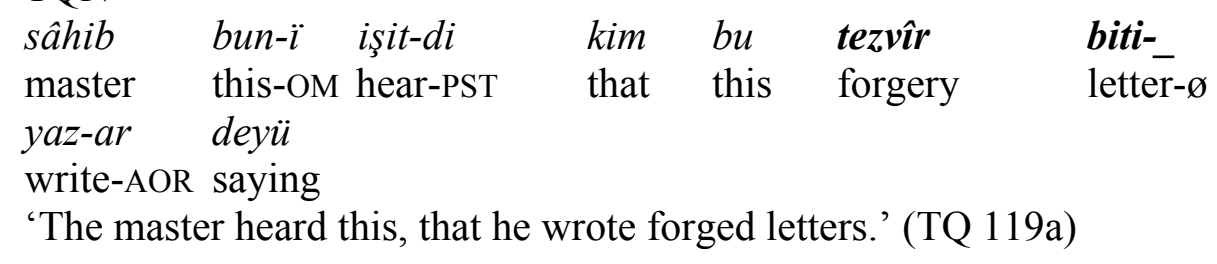

Extreme caution must be exercised in interpreting these results. Although the EPN manuscript lacks the Turko-Persian DOM pattern, while the OAT manuscript for the most part exhibits it, the former is three centuries older than the latter, and so this cannot on its own be taken to mean that Turkic had the pattern before Persian. However, the following observations can be made. First, the pattern found in the PQN, where definites are virtually always marked and indefinites sometimes marked only if they are animate is very similar to patterns found in genetically related languages such as Vafsi and Hindi/Urdu. Next, OAT 
clearly exhibited something very close to the modern Turko-Persian pattern, and this was not a translation effect, since the ENP of the source did not have the feature.

\section{$3 \quad$ Summary and Further Proposal}

The three features that make up the DOM pattern found in Turkish (SW Turkic) and Persian (SW Iranian) are also found in Azerbaijanian (SW Turkic) and Eastern Armenian (Indo-European). Persian, Azerbaijanian, and Eastern Armenian are all spoken in Iranin Azerbaijan.

Most other languages spoken in that region are NW Iranian. These languages show evidence of Feature 1, except Kurmanji, Sorani, and Vafsi, which are located on the western and southern periphery of the region. Evidence regarding the other features is currently lacking.

Analysis of an Old Anatolian Turkish manuscript shows that the pattern was present in SW Turkic as early as the 14th century (predating written evidence of a distinct Azerbaijanian language). The fact that the Persian text from which this was translated lacks the pattern indicates that the pattern was not a translation effect.

Analysis of an Early New Persian text (composed in the 11th and copied in the 14th centuries) shows the pattern for human objects but not for inanimates.

If these texts are representative, one possiblity that suggests itself is that Turkic influence may have eliminated the animacy distinction in Persian. This influence may date from the Safavid state (founded ca. 150), the rulers of which were Persianized Turks who spoke a variety of Middle Azerbaijanian that might actually have been a mixed language incorporating Ottoman elements (Stein 2005: 228).

Much work remains to be done to establish the validity of the proposed isogloss, but the preliminary results are supportive of the hypothesis.

\section{References}

Aissen, Judith. 2003. Differential Object Marking: Iconicity vs. Economy. Natural Language and Linguistic Theory 21 (3): 435-483.

Birnbaum, Eleazar. 1981. Foreward and Introductory Study. In: The Book of Advice by King Kay Kä'us ibn Iskander: The earliest Old Ottoman Turkish Version of his $K \bar{A} B \bar{U} S N \bar{A} M E$. Sources of Oriental Languages and Literature 6: 1-11

Bossong, Georg. 1985. Differentielle Objektmarkierung in den neuiranischen Sprachen. Tübingen: Gunter Narr Verlag.

Bossong, Georg. 1991. Differential Object Marking in Romance and Beyond. New Analyses in Romance Linguistics. Amsterdam/Philadelphia: Benjamins, 143-170. 
Differential Object Marking in Turkic and Persian as a Contact Phenomenon

Brunner, Christopher J. 1977 A Syntax of Western Middle Iranian. Delmar, New York: Caravan Books.

Enç, Mürvet. 1991. The semantics of specificity. Linguistic Inquiry 22, 1-25.

Erdal, Marcel. 2004. A Grammar of Old Turkic. Brill: Leiden, Boston.

Ghomeshi, Jila. 1997. Topics in Persian VPs. Lingua 102: 133-167.

Göksel, Aslı and Celia Kerslake. 2005. Turkish: A Comprehensive Grammar. New York, NY: Routledge.

von Heusinger, Klaus \& Jaklin Kornfilt. 2005. 'The case of the direct object in Turkish: Semantics, syntax and morphology. Turkic Languages 9, 3-44.

Johanson, Lars, 2002. Structural Factors in Turkic Language Contacts. Richmond: Curzon Press.

Karimi, Simin. 2005. A Minimalist Approach to Scrambling. Berlin/New York: Mouton de Gruyter.

Kent, Roland G. 1953. Old Persian: Grammar, Texts, Lexicon. New Haven: American Oriental Society.

Key, Gregory. 2008. Differential Object Marking in a Medieval Persian Text. in: Aspects of Iranian Linguistics, Simin Karimi, Vida Samiian, Donald Stilo, eds. Cambridge Scholars Publishing: Newcastle upon Tyne, UK.

Key, Gregory. 2009. Differential Object Marking as an Areal Trait in Persian and Turkish. Unpublished MA thesis, the University of Arizona.

Megerdoomian, Karine. 2008. Parallel Nominal and Verbal Projections. In Foundational Issues in Linguistic Theory: Essays in Honor of Jean-Roger Vergnaud. Cambridge, Massachusetts: The MIT Press.

Paul, Ludwig. 2003. Early Judaeo-Persian in a historical perspective: The case of the prepositions bē, o, pa(d), and the suffix -rā. Persian Origins - Early JudaeoPersian and the Emergence of New Persian (Collected Papers of the Symposium, Göttingen 1999). Ed. Ludwig Paul, Wiesbaden, 177-194.

Paul, Ludwig. 2008. Some remarks on Persian suffix -râ as a general and historical issue. in: Aspects of Iranian Linguistics, Simin Karimi, Vida Samiian, Donald Stilo, eds. Cambridge Scholars Publishing: Newcastle upon Tyne, UK. 
Raun, Alo. 1969. Basic Course in Uzbek. Indiana University: Bloomington.

Schönig, Claus. Azerbaijanian. In: The Turkic Languages. Ed. Lars Johanson and Éva Ágnes Csató. London: Routledge, 1998: 248-260.

Stein, Heidi. 2005. Traces of Türki-yi Acemi in Pietro della Valle's Turkish Grammar (1620). In: Linguistic Convergence and Areal Diffusion: Case Studies from Iranian, Semitic and Turkic. Éva Ágnes Csató, Bo Isaksson and Carina Jahani. Routledge Curzon: London and New York.

Stilo, Donald L. 2004. Vafsi Folk Tales. Dr. Ludwig Reichert Verlag: Wiesbaden.

Stilo, Donald L. 2005. Iranian as Buffer Zone Between the Universal Typologies of Turkic and Semitic. In: Linguistic Convergence and Areal Diffusion: Case Studies from Iranian, Semitic and Turkic. Éva Ágnes Csató, Bo Isaksson and Carina Jahani. Routledge Curzon: London and New York.

Thackston, W.M. 1993. An Introduction to Persian. Bethesda: Ibex Publishers.

Thackston, W.M. 2006a. Kurmanji Kurdish: A Reference Grammar with Selected Readings. www.fas.harvard.edu/ iranian/Kurmanji/index.html

Thackston, W.M. 2006b. Sorani Kurdish: A Reference Grammar with Selected Readings. http://www.fas.harvard.edu/ iranian/Sorani/index.html

Windfuhr, Gernot. 2009. Dialectology and Topics. In: The Iranian Languages, ed. Gernot Windfuhr. Routledge: London and New York.

Windfuhr, Gernot and John R. Perry. Persian and Tajik. In: The Iranian Languages, ed. Gernot Windfuhr. Routledge: London and New York.

Greg Key

UA School of Middle Eastern \& North African Studies

PO BOX 2101888

Tucson, AZ 85721-0158

gkey@email.arizona.edu 